\title{
Maximum Likelihood Estimates and Determinants of Technical Efficiency of Leafy Vegetable Producers in Akwa Ibom State, Nigeria
}

\author{
Inibehe George Ukpong ${ }^{1} \&$ Idiong Christopher Idiong ${ }^{2}$ \\ ${ }^{1}$ Department of Food Economics and Marketing, School of Agriculture, Policy and Development, University of \\ Reading, United Kingdom \\ ${ }^{2}$ Department of Agricultural Economics and Extension, University of Calabar, Nigeria \\ Correspondence: Inibehe George Ukpong, Department of Food Economics and Marketing, School of Agriculture, \\ Policy and Development, University of Reading, United Kingdom. E-mail: inibehe2000@yahoo.com
}

Received: December 19, 2012 Accepted: January 11, 2013 Online Published: February 17, 2013

doi:10.5539/jas.v5n3p139 URL: http://dx.doi.org/10.5539/jas.v5n3p139

\begin{abstract}
Leafy vegetables are important delicacies in the diet of most people in Nigeria and have played important role in helping to solve food security problems mainly in the rural areas. This study was carried out to determine the influence of some socio-economic and environmental factors on technical efficiency of leafy vegetable producers in Akwa Ibom State, Southern Nigeria. The results show that leafy vegetable production in the study area is female dominated. The Maximum Likelihood Estimates (MLEs) of the Cobb-Douglas stochastic production frontier function indicated that age of vegetable producers have a negative and significant influence on their technical efficiency, while, educational level, farming experience, farm size, household size and soil quality have positive and significant influence on their technical efficiency. The study recommends the formulation and implementation of policies that would encourage establishment of Adult and Continuing Education in the State, and adoption of sustainable systems of farming that will enhance good soil quality and environmental sustainability, with adequate supply of inputs to promote efficient production of vegetables in the area.
\end{abstract}

Keywords: maximum likelihood, technical efficiency, leafy vegetable, akwa ibom, Nigeria

\section{Introduction}

Leafy vegetables are among the major food crops widely cultivated in the tropics. It forms an important part of the economic wellbeing and livelihood for the people.

Study by Mbanasor and Kalu (2008) recorded that vegetables are essential sources of micro-nutrients in human nutrition that act as preventive agents to several ailments. Also, increased vegetable production can improve food security, and provide employment opportunities and additional income to the people. In Nigeria, leafy vegetables are significant dietary components of most traditional delicacies often accompanying legumes (beans) and carbohydrate staples.

In southern Nigeria, vegetable production is very popular due to its high consumption by both rural and urban households. Water leaf (Talinum fruticosum) and pumpkin (Telferia occidentalis) are among the major leafy vegetables grown by farmers in the region (Mbanasor \& Kalu, 2008). However, evidence of low productivity in food crops including vegetable production in Nigeria has been reported due primarily to inefficiency in resource use (Umoh, 2006; Idiong, 2006; Udoh \& Akpan, 2007).

Specifically, studies on small scale production in Akwa Ibom State have shown that the farmers are inefficient in resource use. They adduced this inefficiency to some socioeconomic factors of the producers (Ike \& Inoni, 2006). However, some environmental factors such as soil quality also have influence on farmer's efficiency (Nahm \& Sutummakid, 2003).

This study aimed to examine the influence of some environmental and socio-economic factors on technical efficiency of leafy vegetable producers in Akwa Ibom State of Nigeria. The specific objectives of the study include the following to:

(i) Identify the socio-economic characteristics of leafy vegetable producers in the area. 
(ii) Determine the influence of socio-economic factors such as age, farming experience, farm size and household size, and environmental factors such as soil quality, on the efficiency levels of the leafy vegetable producers in the area.

(iii) Make policy recommendations based on findings of the study.

\subsection{Factors Affecting Efficiency}

Efficiency of production can be considered in different forms such as technical, allocative and economic efficiencies (Farell, 1957). Technical efficiency is the achievement of maximum potential output from a given quantity of inputs under a given technology or the attainment of production goal without wastage. In other words, allocative efficiency is achieved when factors of production are used in proportions that lead to profit maximization. Economic efficiency encompasses both technical and allocative efficiencies, and implies that productions of goods are maximized and goods are produced at their lowest possible cost.

Studies have shown that several factors have significant effects on the efficiency of farmers in food crop production. Such factors include farmers' access to technology (Seyoum, Battese, \& Fleming, 1998). Credit, soil fertility and social capital also affects farmers' efficiency (Binam, Tonye, Wandji, Nyambi, \& Akoa, 2004). Moreover, research by Ajibefun (2002) showed that socio-economic factors such as sex, age, level of education, farmers experience and farm size have influence on the efficiency of small scale farmers in Nigeria.

Study by Weir and Knight (2000) recorded that household size and education positively influenced the level of technical efficiency of farmers. Moreover and Nwaru (2004) recorded that educational level of farmers, farming experience and membership of organization have significant positive effects on farmers' technical efficiency.

Wadud and White (2000) reported that although inefficiency decreases with farm size, farmers with good soils were significantly more technically efficient. Similarly, factors such as land, labour, self-sufficiency have significant relationship with production efficiency (Johnson, 1982). A similar result was also reflected in the study by Abang and Agom (2004) on resource use efficiencies of small holder cassava farmers in Cross River State. More so, Ajibefun (2002) reports that factors of production and inputs such as land, labour, seeds, chemicals and implements had positive signs with the return to scale value of 1.26 which indicates an increasing returns to scale, while Ogundari and Ojo (2006) also recorded positive coefficients of the farm size, labour and planting materials.

\section{Materials and Methods}

This study was carried out in Akwa Ibom State of Nigeria. The State is located in the south-south geopolitical zone of the country. The State has good agro-ecological climate suitable for agricultural production. Its vast water resources, thick green vegetation and massive arable land support cultivation of food and tree crops, as well as, fish farming and livestock production. Crops commonly grown in the area include; vegetables such as, water leaf, fluted pumpkin, tomatoes and garden egg. Others crops such as; maize, cassava, yam, rice, plantain, banana and oil palm are also widely grown in the area.

A multi-stage random sampling procedure was employed to select three Senatorial districts in the State, namely Eket, Ikot Ekpene and Uyo; out of which 40 farmers were selected from each of the three districts. A total of one hundred and twenty (120) vegetable farmers were sampled at farm locations and used for the study.

Data on socioeconomic characteristics of the vegetable producers were analyzed using means, standard deviation, percentages and frequency tables, bar and pie charts. The stochastic frontier production function that incorporated efficiency factors was estimated using the Maximum Likelihood Estimating (MLE) technique and was used in determining the effects of some socioeconomic and environmental factors (Soil quality) on the levels of efficiency of the farmers. It was obtained by collecting soil samples from the vegetable production area and analyzing for different soil fertility parameters such as $\mathrm{pH}$, colour, texture, organic matter content, porosity and electronic conductivity. The Soil quality index (SQI) was then constructed as shown below. These procedures have been used by (Nahm \& Sutummakid, 2003; Brejda, Moorman, Karlen, \& Dao, 2000).

$$
S Q I=[D p H+D O M+D P+D K+D E C] / 5
$$

Where

$$
\begin{aligned}
& \mathrm{DpH}=1 \text { if } \mathrm{pH}=6.5 \text { and }=0 \text { otherwise } \\
& \mathrm{DOM}=1 \text { if } \mathrm{OM}=2 \text { and }=0 \text { otherwise } \\
& \mathrm{Dp}=1 \text { if } \mathrm{P}=20 \text { and }=0 \text { otherwise } \\
& \mathrm{DKi}=1 \text { if } \mathrm{Ki}=80 \text { and }=0 \text { otherwise }
\end{aligned}
$$


$\mathrm{DECi}=1$ if $\mathrm{ECi}=2$ and $=0$ otherwise

$\mathrm{pH}, \mathrm{OM}, \mathrm{P}, \mathrm{K}$ and EC are the $\mathrm{pH}$, Organic matter content, Phosphorus, Potassium and Electronic conductivity respectively which represent soil fertility parameters of the study area. SQI is bounded between 0 and 1 , and the higher the SQI, the better the soil quality.

Soil $\mathrm{pH}$ measures the level of the concentration of hydrogen ions and ranges from highly acidic (1.0) to highly alkaline (14), however, $\mathrm{pH}$ of 6 and 7 are suitable levels for agricultural production. The suitable level of the available form of phosphorus for plant growth is between 13 and $25 \mathrm{ppm}$ (parts per million), while potassium (K) is suitable for plant growth if its availability exceeds $80 \mathrm{ppm}$. The organic matter (OM) stores and provides essential nutrients useful for plant growth, while electrical conductivity (EC) is an indicator of the levels salinity of the soil such that the higher the EC the higher the salinity of the soil. Salinity restricts the growth of most plants including vegetables (Tisdale, Nelson, Beaton, \& Havlin, 1993).

The stochastic frontier production analysis allows for error measurement while other random disturbances that are not observable have been captured in the model. Environmental variables such as index for the soil quality (SQI) defined in section 2.0; are assumed to have effects on the mean efficiency of each senatorial district in the study area. The influence of the socio-economic and environmental factors on the computed efficiency indices were determined by incorporating them directly into the frontier model since they have influence on a priori basis on efficiency. The model is specified as follows:

$$
T E=\boldsymbol{\delta}_{0}+\boldsymbol{\delta}_{1} \mathbf{Z}_{1}+\boldsymbol{\delta}_{2} \mathbf{Z}_{2}+\boldsymbol{\delta}_{3} \mathbf{Z}_{3}+\boldsymbol{\delta}_{4} \mathbf{Z}_{4}+\boldsymbol{\delta}_{5} \mathbf{Z}_{5}+\boldsymbol{\delta}_{6} \mathbf{Z}_{6}+\boldsymbol{\delta}_{7} \mathbf{Z}_{7}+\boldsymbol{\delta}_{8} \mathbf{Z}_{8}+\boldsymbol{\varepsilon}_{i}
$$

Where,

$\mathrm{TE}=$ technical efficiency

$\mathrm{Z}_{1}=$ producer's age (years)

$Z_{2}=$ farming experience (years)

$Z_{3}=$ education (years of schooling)

$\mathrm{Z}_{4}=$ farm size (hectares)

$\mathrm{Z}_{5}=$ Household size (number)

$\mathrm{Z}_{6}=$ Soil quality index (numbers)

$\boldsymbol{\delta}_{1}-\boldsymbol{\delta}_{\mathbf{6}}$ are coefficients to be estimated while $\boldsymbol{\delta}_{\mathbf{0}}=\mathrm{Y}$ - Intercept

\section{Results and Discussion}

\subsection{Socio-Economic Characteristics of the Vegetable Producers in Akwa Ibom State}

Table 1. Frequency distribution of farmers according to age, sex and house hold size

\begin{tabular}{lll}
\hline Farmer's age (Years) & Number of Respondents & Percentage \\
\hline $20-30$ & 12 & 10 \\
$31-40$ & 50 & 42 \\
$41-50$ & 40 & 33 \\
Above 50 & 18 & 15 \\
\hline Total & $\mathbf{1 2 0}$ & $\mathbf{1 0 0}$ \\
\hline Mean $=\mathbf{4 1}$ & & Percentage \\
\hline Sex & Number of respondents & 100 \\
Female & 120 & 0 \\
Male & 0 & $\mathbf{1 0 0}$ \\
\hline Total & $\mathbf{1 2 0}$ & 13 \\
\hline Household Size & & 52 \\
$1-4$ & 16 & 35 \\
$5-8$ & 62 & $\mathbf{1 0 0}$ \\
$9-12$ & 42 & \\
\hline Total & $\mathbf{1 2 0}$ & \\
Means $\chi \quad \mathbf{8}$ & & \\
\hline
\end{tabular}


Table 1 indicates that 85 percent of the sampled vegetable farmers in the State were between the age range of 20 and 50 years. The mean age of the farmers is 41 which is within the economically active and high productive age bracket. Idiong (2006) had opined that persons in this age bracket are apt at adopting improved practices since they are not risk averse. However, only 18 (15 percent) of the sampled farmers were above 50 years of age. It also shows that leafy vegetable production in the State is female dominated 100 percent of the respondents were females. This confirms the report by (Idiong, Ekpe, Charles, \& Udoh, 2002), that waterleaf is a major source of income of women farmers in the Southern part of Nigeria.

Household size distribution of the vegetable producers in the State shows that majority ( 52 percent) of the producers had between 5 and 8 individuals in their households. The average household size of the farmers was 8 persons. Household size can determine the amount of farm family labour available to the farmer, hence, helping to reduce the constraints on labour cost associated with agricultural production. However, age composition of a household is a determinant of labour availability such that where majority of the farm family members are very old or of school age, they may not be capable or readily available at all times for farm work (Idiong, 2006).

Table 2. Frequency distribution of waterleaf producers according to educational level and farming experience

\begin{tabular}{ccc}
\hline Level of Education & Number of Respondents & Percentage \\
\hline No formal Education & 12 & 10 \\
Primary Education & 78 & 65 \\
Secondary Education & 24 & 20 \\
Higher Education & 6 & 5 \\
\hline Total & 120 & 100 \\
\hline Farming Experience (Years) & 38 & 32 \\
\hline $1-5$ & 46 & 23 \\
$6-10$ & 28 & 7 \\
$11-15$ & 8 & 100 \\
Above 15 & 120 &
\end{tabular}

Higher Education: Any education level above the secondary school level.

The result in table 2 indicates that majority ( 90 percent) of the farmers were literate and have attained some levels of formal education. Majority (65\%) had attained the primary school level of education. Education is an important factor in enhancing productivity.

The result also shows that majority (61 percent) of the vegetable producers had between 6 and 15 years' farming experience in leafy vegetable production, however, as many as 38 (32 percent) of the farmers had as low as 1-5 years farming experience. Farming experience is also important in increasing production and efficiency in resource use.

\subsection{Maximum Likelihood Estimates (MLEs) of Determinants of Technical Efficiency of the Vegetable Producers}

Table 3. Maximum likelihood estimates (MLEs) of determinants of technical efficiency of vegetable producers in Akwa Ibom State

\begin{tabular}{llll}
\hline Variables & Coefficients & Standard errors & t-ratios \\
\hline Constant & -0.3832 & 0.5332 & -0.719 \\
Producer's age $\left(\mathrm{Z}_{1}\right)$ & -0.2370 & 0.0645 & $3.67 * * *$ \\
Farming experience $\left(\mathrm{Z}_{2}\right)$ & 0.7865 & 0.3447 & $2.28^{* *}$ \\
Education $\left(\mathrm{Z}_{3}\right)$ & 0.2537 & 0.0556 & $4.56^{* * *}$ \\
Farm size $\left(\mathrm{Z}_{4}\right)$ & 0.2434 & 0.1059 & $2.32^{* *}$ \\
Household size $\left(\mathrm{Z}_{5}\right)$ & 0.6821 & 0.2349 & $2.90^{* * *}$ \\
Soil quality $\left(\mathrm{Z}_{6}\right)$ & 0.2333 & 0.0876 & $2.663^{* *}$ \\
\hline
\end{tabular}

Note: $* * *$ Significant at $1 \%, * *$ Significant at $5 \%$ level.

Source: Computed from field survey data 2010 using frontier 4.1 by Coelli (1994). 
The results in Table 3 are the Maximum likelihood estimates of the determinants of technical efficiency of leafy vegetable producers in Akwa Ibom State.

The results indicate that the coefficient of producer's age $\left(Z_{1}\right)$ has a negative sign and is significant at one percent level. This implies that the age of a vegetable producer inversely influences his or her level of technical efficiency, such that the older a vegetable producer becomes the lower his or her technical efficiency level will be. In other words older vegetable producers are less efficient than the younger ones. Research by Nwaru (2004); Ajibefun and Aderinola (2003) reported that younger farmers are innovative, able and willing to take risks and physically strong to do the manual farm work typical of subsistence agriculture unlike the older farmers. In other words, older farmers are likely to depend on their usual systems of farming with less interest for adoption of improved technology and extension services that would enhance their technical efficiency.

The coefficient of farming experience $\left(\mathrm{Z}_{2}\right)$ is positive and significant at the 5 percent level. It indicates that vegetable producers with many years of farming experience in vegetable production have higher levels of technical efficiency than those with fewer years of farming experience. Research by Ike and Inoni (2006) also recorded a positive and significant coefficient of farming experience in relation to production efficiency; Idiong (2006) reported that farmers sometimes count on their experience in their bid to efficiently utilize their scarce resources.

The coefficient of education $\left(Z_{3}\right)$ is also positive and significant at the one percent level. The implication is that the level of technical efficiency of a vegetable producer will increase with his or her level of education. Idiong (2006) asserted that the level of a farmer's education determines his/her managerial competence. That is, an educated farmer has the capacity to understand and adopt improved technology that would shift his or her production frontier upwards. Such a farmer also has the mental ability to process information, select inputs and allocate them across competing uses. Education also enables a farmer to make better decisions to promote increased production. The result agrees with the reported by Ajibefun and Aderinola (2003) and Idiong (2007). However, Bravo and Evenson (1994) reported a non-significant effect of education on farmers' efficiency and concluded that education surely increases efficiency but lower levels of education, seldom does.

The coefficient of farm size $\left(\mathrm{Z}_{4}\right)$ is positive and significant at the 5 percent level. It means that vegetable producers with larger farm sizes have higher levels of efficiency than those with relatively smaller sizes.

The positive and significant coefficient of household size $\left(Z_{5}\right)$ is an indication that increase in family size would result in increased levels of technical efficiency. Vegetable production often requires a lot of farm hands and therefore, increases in household size makes labour readily available given the high cost of hired farm labour in the study area.

More so, the coefficient of soil quality was positive and significant at 5 percent level. This indicates that improvement environmental quality such as soil quality will lead to significant increase in efficiency.

\section{Conclusion and Policy Recommendations}

The analyses in this study have shown that, leafy vegetable production in Akwa Ibom State is female dominated and they are not fully technically efficient in their resource use. Age, farm size, farming experience, education, Soil quality and household sizes were some important policy variables that were found to have significant influence on the levels of technical efficiency of the vegetable producers in the State. Given these results, it is expected that the implementation of policy options discussed below will go a long way in addressing the technical inefficiency of the leafy vegetable producers in the State.

The negative effect of age on technical efficiency levels of the vegetable producers in the area can be addressed by the formulation and implementation of policies that would encourage younger people to delve into vegetable production while also assisting the older ones to remain in production. Such policies should be able to bring about easy access to important inputs such as credit, fertilizer, land and extension activities among others.

Since farming experience of the vegetable producers have positive and significant effect on their technical efficiency, it is of immense importance that experienced producers should be encouraged to continue in vegetable production in the State by implementing policies in that direction. New vegetable farmers can be encouraged to learn relevant production skills from experienced farmers and develop productive strategies based on failures and successes of experienced farmers. Such efforts should also be supported by professional extension services.

Moreover, since education also has positive and significant influence on the farmers' technical efficiency, it is therefore important that policies that would encourage these producers to acquire some form of basic formal education (at least the primary level) should be formulated and implemented in the State. Achieving this would be by strengthening the capacity of the Adult and Continuing Education centers already established in the area. 
The formulation and implementation of policies and programmes that would create off-farm employment opportunities would help to address family labour saturation problem which is common in small sized agricultural production.

Soil quality has positive and significant coefficient at 5 percent level, indicating that increased improvement in soil quality will promote increased technical efficiency of vegetable producers in the area. Therefore, farmers should be encouraged to adopt sustainable farming practices that will enhance good soil quality supported with policies that will discourage soil degradation and promote environmental sustainability. Such practices may include adoption of the slash and mulch system instead of the usual bush burning, as well as, practices that will prevent or reduce the incidence of soil erosion, flood and environmental pollution.

On the whole, since leafy vegetable production in the area is female dominated, it is imperative that policies are made to promote profitable vegetable production as a strategy for poverty alleviation among women.

\section{References}

Abang, S. O., \& Agom, D. I. (2004). Resource Use Efficiency of Small Holder Farmers: The Case of Cassava Producers in Cross River State. Nigerian Journal of Food, Agriculture and Environment, 2(3\&4), 87-90.

Ajibefun, I. A., \& Aderinola, E. (2003). Determinants of Technical Efficiency and Policy Implications in Traditional Agricultural Production. Empirical Study of Food Crop Farmers "Work in Progress Report Presented at the Bi Annual Research Workshop of AERC, Nairobi-Kenya, May, $24^{\text {th }}-29^{\text {th }}$.

Ajibefun, I. A. (2002). Analysis of Policy issues in Technical Efficiency of Small Scale Farmers using the Stochastic Frontier Production Function with application to Nigerian Farmers. Paper Prepared for presentation at the International Farm Management Association Congress, Wageningen, Netherland.

Binam, J. N., Tonye, J., Wandji, N., Njambi, G., \& Akoa, M. (2004). Factors Affecting the Technical Efficiency among Small holder Farmers in the Slash and Burn Agriculture Zone of Cameroon. Food Policy, 29(5), 531-545. http://dx.doi.org/10.1016/j.foodpol.2004.07.013

Bravo-Ureta, B. E., \& Evenson, R. E. (1994). Efficiency in Agricultural production: The case of Peasant Farmers $\begin{array}{lllll}\text { in Eastern Paraguay. Agricultural Economics, } & \text { 10(1), }\end{array}$ http://dx.doi.org/10.1016/0169-5150(94)90037-X

Brejda, J. J., Moorman, T. B., Karlen, D. L., \& Dao, T. H. (2000). Identification of Regional Soil Quality Factors and Indicators: I. Central and Southern high Plains. Soil Science Society of America Journal, 64, 2115-2124. http://dx.doi.org/10.2136/sssaj2000.6462115x

Coelli, T. J. (1994). A Guide to Frontier 4. 1: A Computer Programme for Stochastic Frontier Production and Cost Function Estimation. Department of Economics, University of New England, Armidale.

Farell, J. M. (1957). The Measurement of Productive Efficiency. Journal of Royal Statistical Society (Series A: General), 120(111), 253-290. http://dx.doi.org/10.2307/2343100

Idiong, I. C. (2006). Evaluation of Technical, Allocative and Economic Efficiencies in Rice Production Systems in Cross River State, Nigeria. Unpublished Ph.D. Thesis Department of Agricultural Economics, Michael Opara University of Agriculture, Umudike, Umuahia, Nigeria.

Idiong, I. C. (2007). Estimation of farm level technical efficiency in small-scale swamp Rice Production in Cross River State of Nigeria: A Stochastic Frontier Approach. World Journal of Agricultural Science, 3(5), 653-658.

Idiong, I. C., Ekpe, E. E., Charles, A. I., \& Udoh, E. J. (2002). Socio-Economic Determinants of water Leaf Production in Calabar Municipality and Calabar South Local Government Area of Cross.River State. Global Journal of Pure and Applied Sciences, 8(2), 239-243. http://dx.doi.org/10.4314/gjpas.v8i2.16037

Ike, P. C., \& Inoni, O. E. (2006). Determinants of Yam Production and Economic Efficiency among Small-Holder Farmers in Southeastern Nigeria. Journal of Central European Agriculture, 7(2), 337-342.

Johnson, D. T. (1982). The Business of Farmer. A Guide to Farm Business Management in the Tropics. London Macmillan Publishers Limited.

Mbanasor, J. A., \& Kalu, K. C. (2008). Economic Efficiency of Commercial Vegetable Production System in Akwa Ibom State, Nigeria: A Translog Stochastic Frontier Cost Function Approach. Tropical and Subtropical Agro-Ecosystems, 8, 313-318. 
Nahm, D., \& Sutummakid, N. (2003). Efficiency of Agricultural Production in the Central Region of Tha. Department of Economics, Macquarie University, Sydney, Australia.

Nwaru, J. C. (2004). Rural Credit Market and Arable Crop Production in Imo State of Nigeria. Unpublished Ph. D. Dissertation, Michael Opara University of Agriculture, Umudike, Nigeria.

Ogundari, K., \& Ojo, S. O. (2006). An Examination of Technical, Economic Allocative Efficiency of Small Farms: The Case Study of Cassava Farmers in Osun State of Nigeria. Journal of Central European Agriculture, 7(3), 423-432.

Seyoum, E. T., Battese, G. E., \& Fleming, E. M. (1998). Technical Efficiency and Productivity of Maize Producers in Eastern Ethiopa. A Study of Farmers within and Outside the Sadakawa-Global 2000 Project. Agricultural Economics, 19, 341-348. http://dx.doi.org/10.1016/S0169-5150(98)00037-1

Tisdale, S. L., Nelson, W. L., Beaton, J. D., \& Havlin, J. L. (1993). Soil Fertility and Fertilizers (5th ed.). New Jersey: Prentice Hall.

Udoh, E. J., \& Akpan, S. B. (2007). Measuring technical efficiency of waterleaf (Talinum triangulare) production in Akwa Ibom State, Nigeria. American-Eurasian Journal of Agriculture and Environmental Science, 2(5), 518-522.

Umoh, G. S. (2006). Resource use Efficiency in Urban Farming: An Application of Stochastic Frontier Production Function. International Journal of Agriculture and Biology, 8(1), 37-44.

Wadud, A., \& White, B. (2000). Farm Household Efficiency in Bangladesh: A Comparison of Stochastic Frontier and DEA Methods. Applied Economics, 32(13), 173. http://dx.doi.org/10.1080/000368400421011665-16

Weir, S., \& Knite, J. (2000). Education Externalities in Rural Ethiopia: Evidence from Average and Stochastic Frontier Production Functions. Working Paper, CSAEWPS/2000.4, Centre for the Study of African Economics, University of Oxford. 